It has nevertheless provided one of the few instances of impressive vitality in a lethargic and demoralized profession.

Sidney Monas

University of Texas at Austin

To THE EDITOR:

I hope you will grant me space in the Slavic Review to correct an unfortunate and regrettable error I made in my article "Laying a Legend to Rest: The Poet Kapnist and Ukraino-German Intrigue," which you published in the Slavic Review for September 1971. In that article I expressed by implication my suspicion that an article published by Georg Sacke in the Zeitschrift für slavische Philologie in 1941, "V. V. Kapnist und seine Ode 'Na rabstvo," was in effect a "patriotic" contribution to the war against the Soviet Union launched by Hitler on June 22 of that year. It turns out that I could scarcely have been more wrong on this point. My good friend and former colleague at Indiana University, Professor F. T. Epstein, the well-known German historian, tells me that Georg Sacke lived and died a convinced Communist, perishing in a concentration camp as one of the many scholarly victims of the Nazi terror.

WiLliam B. EDgerton

Indiana University

\title{
The New Hungarian Quarterly
}

No. 47, Autumn 1972

\section{A special number on GYÖRGY LUKÁCS (1885-1971)}

\section{Containing:}

Chapters from two unpublished works:

"ONTOLOGY" and "HEIDELBERG AESTHETICS"

His Preface to "Art and Society"

Letters to a friend

His life in pictures

Appreciations and reminiscences by friends and contemporaries

For further information write to the Editorial Offices of

THE NEW HUNGARIAN QUARTERLY

Budapest 5, P.O. Box 57, Hungary 